\title{
The Combined Use of Video Modeling and Social Stories in Teaching Social Skills for Individuals with Intellectual Disability
}

\author{
Seray Olçay Gül ${ }^{1}$ \\ Hacettepe University
}

\begin{abstract}
There are many studies in the literature in which individuals with intellectual disabilities exhibit social skills deficits and which show the need for teaching these skills systematically. This study aims to investigate the effects of an intervention package of consisting computer-presented video modeling and Social Stories on individuals with intellectual disabilities in emerging adulthood, in teaching social skills. A multiple-probe design across participants was used to assess the effectiveness of the intervention package. Results showed that, all participants acquired the target social skills with $100 \%$ accuracy, maintained these skills over time, and generalized them across settings, conditions, and people. Additionally, social validity data collected with semi-structured interview were positive in general. Study findings were discussed within the framework of the literature and recommendations have been given regarding this intervention and further research.
\end{abstract}

\section{Keywords}

Video modeling • Social Stories $\bullet$ Single subject research $\bullet$ Teaching social skills $\bullet$ Individuals with intellectual disabilities

\footnotetext{
* Author is grateful to Dr. Elif Tekin-İftar, for her insightful review and feedbacks.

1 Correspondence to: Seray Olçay Gül (PhD), Department of Special Education, Faculty of Education, Hacettepe University, Beytepe, Ankara 06800 Turkey. Email: serayolcaygul@hacettepe.edu.tr

Citation: Olçay Gül, S. (2016). The combined use of video modeling and social stories in teaching social skills for individuals with intellectual disability. Educational Sciences: Theory \& Practice, 16, 83-107. http://dx.doi.org/10.12738/estp.2016.1.0046
} 
Intellectual disability has been addressed by different disciplines up to the present and has been defined differently depending on the views of different disciplines. Preliminary definitions of intellectual disability underline biological and medical criteria whereas educational definitions stand out when teachers and psychologists are more interested in the subject (Heward, 2003). Among these definitions, the one provided by the American Association on Intellectual and Developmental Disability (AAIDD) is the most widely accepted. Apart from this one, in the Diagnostic Statistical Manual of Mental Disorders (DSM) by the American Psychological Association (APA) and in the system of International Statistical Classification of Diseases and Related Health Problems (ICD-10) of the World Health Organization (WHO), definitions have also been provided (Sucuoğlu, 2010).

AAIDD (2002) defines intellectual disability as a disability characterized by significant limitations in intellectual functioning; conceptual, social and practical skills; and adaptive behavior which originate before the age of 18 (Eripek, 2009; Hourcade, 2002). Different from AAIDD, the DSM-5 manual (2013) uses adaptive functioning instead of adaptive behavior in its definition and indicates that adaptive functioning includes three domains (conceptual, social and practical) which determine how well an individual copes with everyday tasks (APA, 2013). On the other hand, the definition provided by ICD-10 (1993) underlines the incomplete development of the mind and disorders in cognitive, linguistic, motor, and social abilities that play a role in determining level of intelligence (Eripek, 2009; Sucuoğlu, 2010). It is worth noting that all of these definitions refer to disabilities in terms of conceptual, social, and practical skills that enable individuals to carry out everyday tasks apart from disabilities in mental functions. This is an indicator of the fact that social skills deficits are one of the criteria taken into account when determining intellectual disabilities.

The literature has emphasized that social skills deficits, which are defined as the inability to learn various social skills or the inability to use previously acquired social skills in appropriate situations and settings, are common among individuals with intellectual disabilities (McCoy \& Hermansen, 2007; Vuran 2012). The reasons why individuals with intellectual disabilities exhibit social deficits more may include the manifestation of behavioral and cognitive disabilities in addition to having limited random learning skills and interactions with peers with typical development (Huang \& Cuvo, 1997; Sargent, 1991), experiencing of rejection from their peers with typical development, and being rejected by circles due to a negative perception (Sazak, 2003). These reasons negatively affect the decisions of individuals with intellectual disabilities in terms of how they should act in society, creating behavioral problems and negatively affecting the acquisition of social skills through environmental observation and modeling (Çiftçi \& Sucuoğlu, 2004; Sargent, 1991). 
Overcoming social skills deficits for individuals with intellectual or other developmental disabilities can be possible by providing social skills which are taught systematically (Begun, 1996; Sugai \& Lewis, 1996). In this respect, direct teaching, social reinforcement, feedback, giving clues, incidental teaching, shaping, being a model, behavioral rehearsal, cooperative learning, peer learning, video modeling, Social Stories, and pivotal response teaching are commonly used strategies for teaching social skills to individuals with intellectual disabilities (Baker, 2004; Çolak, 2007; Olçay-Gül, 2012; Sargent, 1991). Video modeling and Social Stories have been the most prominent strategies in recent years.

Video modeling was developed on the assumptions of observational learning theory. It is an intervention which uses video modeling instead of live modeling for teaching a new behavior or changing an existing one; it is implemented by getting learners to watch all the steps of a target behavior from a video before being taught (Bellini, Akullian, \& Hopf, 2007; Charlop-Christy, Le, \& Freeman, 2000; Nikopoulos \& Keenan, 2006; Sansosti \& Powell-Smith, 2008). Coupled with technological advancements, much research has shown the widespread use of video modeling for teaching social skills (Akmanoğlu \& Tekin-İftar 2011; Avc1oğlu, 2013; Bellini et al., 2007; Bidwell \& Rehfeldt, 2004; Buggey, 2005; Charlop-Christy \& Daneshvar, 2003; Charlop-Christy et al., 2000; D’Ateno, Mangiapanell, \& Taylor, 2003; Emecen, 2008; Graetz, Mastropieri, \& Scruggs, 2006; Kroeger, Schultz, \& Newsom, 2007; Nikopoulos \& Keenan, 2003; Olçay-Gül \& Vuran, 2010). Examining the research in terms of participant characteristics, with the exception of three that had been conducted with individuals with intellectual disabilities (Avc1oğlu, 2013; Bidwell \& Rehfeldt, 2004; Emecen, 2008), all were seen to be conducted with individuals with autism spectrum disorder (ASD) or Asperger's Syndrome. Research studies have additionally been seen carried out with individuals between the ages of 3 and 15; only one research has been conducted with adults (Bidwell \& Rehfeldt, 2004) and none have been conducted with individuals between the ages of 18 and 25, the age of emerging adulthood. Moreover, when these studies were examined in terms of the characteristics of the model, typical models such as a familiar peer, familiar adult, non-familiar peer, non-familiar adult or self were seen to be used except for one research in which a model with a disability had been used (Bidwell \& Rehfeldt, 2004). Conversation skills (i. e., How are you?, See you, etc.) (Charlop-Christy et al., 2000; Sansosti \& Powell-Smith, 2008; Scattone, 2008), skills for understanding emotions and responding appropriately to them (Bernad-Ripoll, 2007; Charlop-Christy et al., 2000), and social and reciprocal play skills (Charlop-Christy et al., 2000; D'Ateno et al., 2003) were found to have been practiced in analyzing the literature in terms of social skills. Findings revealed that video modeling was effective in teaching social skills addressed in the research. 
Another strategy that has become increasingly prevalent in teaching social skills is Social Stories (Olçay-Gül, 2012). Social stories are short stories prepared in a certain format and written according to certain rules; they objectively define a skill, event, or situation in order to explain social situations, teach social skills, and enable students to appropriately respond in the social situations that they face (Barry \& Burlew, 2004; Gray, 1998; Gray \& Garand, 1993; Scattone, 2002). There are many studies in the literature that have examined the effectiveness of Social Stories in teaching different social skills (Croizer \& Tincani, 2006; Delano, 2003; Delano \& Snell, 2006; Dodd, Hupp, Jewell, \& Krahn, 2008; Norris \& Dattilo, 1999; OlçayGül \& Tekin-İftar, 2012; Reichow \& Sabornie, 2009; Schneider \& Goldstein, 2010; Smith, 2001; Swaine, 2004; Washburn, 2006; Xin \& Sutman, 2011). The majority of these research has been conducted with individuals with ASD. Only two of them were carried out with individuals with learning disability (Kalyva \& Agaliotis, 2009) and behavioral problems (Toplis \& Hadwin, 2006). When examining these research in terms of participants' age groups, they were seen to mostly be carried out with individuals between the ages of 7 and 16; no studies were conducted on individuals with intellectual disabilities older than 18 , and only a handful were carried out with children between the ages of 3 and 6 (Croizer \& Tincani, 2006; Kuoch \& Mirenda, 2003; Lorimer, Simpson, Myles, \& Ganz, 2002; Schneider \& Goldstein 2010; Smith, 2001). Analyzing the research in terms of the practiced social skills, asking for a favor (Delano, 2003; Swaine, 2004), greeting (Reichow \& Sabornie, 2009), forming social interactions (Sansosti \& Powell-Smith, 2006; Smith, 2001), turn-taking and not interrupting others' words (Washburn, 2006), and speaking by holding the floor (Xin \& Sutman, 2011) were found to be practiced. Aside from this, the findings in the literature showed that Social Stories have been effective in teaching social skills.

It is seen in the literature that some research combined video modeling and Social Stories together and tested its intervention effects in teaching social skills (BernadRipoll, 2007; Cigrand, 2011; Kagohara et al., 2013; Sansosti \& Powell-Smith, 2008; Scattone, 2008; Wilkinson, 2010). Bernard-Ripoll (2007) investigated the effect of using video modeling and Social Stories together for teaching the skills of understanding and becoming aware of and responding appropriately to emotions to an eight-year-old child with Asperger's Syndrome. The findings showed that intervention package was effective in teaching social skills to a child with Asperger's Syndrome. The multiple baseline design across participants was used by Sansosti and Powell-Smith (2008) for teaching the skills of maintaining communication and participating in play activity to three children with Asperger's Syndrome whose ages ranged between 6 and 10, and by Kagohara et al. (2013) for teaching the skill of greeting an adult to two 10-year-old children with Asperger's Syndrome in these studies investigating the effectiveness of using video modeling and Social Stories together. The findings of both studies revealed that using video modeling and Social Stories together was effective for teaching target 
social skills. The effectiveness of using video modeling and Social Stories together was investigated by Scattone (2008) in teaching the skills of making eye contact, smiling, and initiating communication to a nine-year-old child with Asperger's Syndrome, and by Wilkinson (2010) in teaching the skills of making eye contact and giving appropriate replies to questions to two children between the ages of 7 and 9 diagnosed with highfunctioning autism. According to the findings in which multiple baseline design across behaviors have been used, using video modeling and Social Stories together has been effective in teaching the target social skills. Additionally, Cigrand (2011) employed qualitative analysis in a research on the effectiveness of using video modeling and Social Stories together for teaching social and adaptive skills to children with ASD between the ages of 5 and 13. In these research, both the videos and stories were seen to be prepared related to the target social skill, then the prepared materials were presented using a computer and iPad. The videos and Social Stories prepared for the target social skills were presented successively. However no intervention in which a Social Story and recorded footage of a scenario prepared in compliance with the story had been combined into a single video and presented by computer, then, the effect of presented intervention on individuals with intellectual disabilities aged between 18 and 25 was examined.

Moreover, it was seen that research using video modeling, Social Stories, and combining these two strategies together were conducted with generally individuals with the ASD diagnosis, and video modeling and Social Stories were effective in teaching social skills to these individuals; however, there was a paucity in research examining the combined effects of these two strategies in teaching social skills to individuals with intellectual disabilities. Also, research examining effectiveness of mentioned strategies in teaching social skills to individuals in emerging adulthood (18-25 ages) covering the period between adolescence and adulthood. Except for one research (Bidwell \& Rehfeldt, 2004), no research using peers with intellectual disabilities as models during teaching with video modeling was found.

Last but not the least, video modeling and Social Stories are considered to be clear, concrete, and visually identifiable target behaviors, and they are seen as entertaining by individuals with disabilities (Andrews, 2004; Charlop-Christy et al., 2000; Wheeler, 2005). They can increase the effectiveness of teaching with a computer considering that computer-presented teaching is expected to be more common in the future (Sansosti \& Powell-Smith, 2008). Departing from the mentioned limitations and points, this study aims to investigate the effectiveness of an intervention package of computerpresented video modeling and Social Stories in teaching the "say 'get better soon"" skill to individuals with intellectual disabilities between the ages of 20 and 25. For this purpose, this study attempts to answer the following questions: (a) Is the intervention package effective in the acquisition of the "say 'get better soon" skill by individuals with intellectual disabilities? (b) Is the intervention package effective in maintaining 
the acquired social skill by individuals with intellectual disabilities after the first and fourth weeks? (c) Is the intervention package effective in enabling individuals with intellectual disabilities to generalize the acquired social skill across settings, conditions and people? (d) What are the opinions (social validity) of the participating individuals with intellectual disabilities and their teachers about the intervention and the social skills that were taught? Video modeling and Social Stories, which can be entertainingly practiced in a short time, are considered easy to use at home or in school, able to be used by different individuals over and over once prepared (OlçayGül, 2012; Vuran \& Olçay-Gül, 2012), and able to make a contribution to the national and international literature as well as the experts, interventionists, and families who have children with this disability by means of meeting an important requirement of the intervention thanks to these features. Using peers with intellectual disabilities as models in teaching social skills is also thought to be able to shed light on the literature and interventionists in terms of its effectiveness.

\section{Method}

This section provides explanations about the research model, dependent and independent variables, participants, settings, materials, general procedures, data collection, and analysis.

\section{Research Model}

A multiple probe design with probe conditions across participants was used in order to evaluate the effect of the intervention package on learning a target social skill by the participants in emerging adulthood. Experimental control was built in when the participant was responding at or near to baseline levels during full probe conditions before the intervention package had been introduced and the criterion was reached only after the intervention package was introduced (Tekin-İftar, 2012a).

In the study, the following factors affecting internal validity were controlled: external factors, by explaining to people around the participants not to teach any target social skills; maturation, by ensuring that the intervention was completed as soon as possible; participant selection bias, by self-comparing the participants in terms of the pre- and post-intervention data; measurement effect, by collecting interobserver reliability and procedural reliability data and by ensuring the interventions were performed consecutively during the study; and participant loss, by working with voluntary participants who would attend regularly. In the study, factors affecting external validity were controlled by means of taking necessary precautions such as implementing and withdrawing the package program for both the participant and across different participants, explaining the baseline level clearly and in detail, and defining all the characteristics of the intervention settings and participants in detail (Kennedy, 2005). 


\section{Dependent and Independent Variable}

The dependent variable of the study was the participants' learning level of the target social skill ("say 'get better soon""). In the process of determining the target social skill, the participants' individualized education program (IEP) was examined and individual interviews with their teachers were also performed. The subjects of discussion in these individual interviews were which social skills would be included in this year's IEP as an objective and which ones were primarily required to be learned. The IEPs of all participants were seen to include the skill of using expressions appropriate to different situations for everyday tasks of life as an objective. In parallel with the teachers' instruction, expressions not included in the behavioral repertoire of the participants were listed and "get better soon," which was absent for all of the participants, was selected as the target skill. The skill of "say 'get better soon" was defined as the participant making eye contact and saying "get better soon" within 4 seconds to the person before them after this person showed or said they were ill (by sneezing, coughing, or when asked how they were and replying with expressions such as "I am sick, very sick,"); this would then be recorded as a correct response for the participant. Incorrect responses were recorded when a participant did not respond within 4 seconds or used any other expression besides "get better soon" after the person in front of the participant showed or expressed that they were sick. During the evaluation process of the skill "say 'get better soon" participants were given the opportunity to meet with five people who showed and expressed that they were sick in every trial. Controlled event recording was utilized across all participants. The researcher planned the events, settings, and stimuli which may elicit the target social skills. The independent variable of this study was the intervention package of computer-presented video modeling and Social Stories developed for the participants' acquisition of the target social skill.

\section{Participants}

The participants of the study were comprised of the learner participants, peer model, researcher, observers, and people presenting stimuli that elicit the target skill.

Learner participants. In order to select participants, interviews were held with the principal and teachers of a special education and rehabilitation center in Ankara, Turkey to determine which students were emerging into adulthood with social skills deficits and which objectives related to social skills were in their IEP. The students who were determined were expected to be able to satisfy four prerequisite characteristics: (a) imitate non-verbal skills, (b) imitate verbal skills, (c) direct their attention to the TV for ninety seconds, and (d) follow instructions involving an item and an action. Assessments were performed in the Ankara Numune Training and Research Hospital to determine whether or not the participants had the prerequisite skills; they were 
observed to see if they could imitate basic displayed movements (e.g. "clapping, bouncing"), follow basic issued commands (e.g. say "Hello" or "How are you?"), direct their attention to the TV for ninety seconds after being instructed to "let's watch a film on TV," and respond to instructions such as "take the pen," or "throw the ball." The students with these prerequisite skills were asked if they wanted to participate in the study and permission was taken from their families.

The first participant was 23-year-old Nedim (pseudonymous). As a result of his assessment, Nedim's IQ was measured as 35-49, and he was diagnosed with moderate intellectual disability. Nedim had attended an inclusive education course in primary and secondary school before leaving school. Nedim displayed a performance close to his peers in gross and fine motor skills. He could imitate movements made with items and without items, as well as two-word expressions. He could also follow instructions of three or more actions and direct his attention to an activity for approximately ten minutes. Moreover, he could say the colors, shapes, and names of items shown to him, do skip counting between 1 and 100, perform simple addition and subtraction, read by spelling, and write spoken words and sentences with assistance. However, he had limited social skills when using expressions appropriate to a social situation, cooperating with peers, asking for information, and expressing emotions.

The second participant was 25-year-old İsmail (pseudonymous). As a result of his assessment, İsmail's IQ was determined as 50-55 and he was diagnosed with mild intellectual disability. İsmail had attended an inclusive education in primary school and then left school. He could imitate movements made with items and without items. İsmail displayed a performance close to his peers in gross and fine motor skills. $\mathrm{He}$ could also imitate words, follow instructions with three or more actions, and direct his attention for 5 minutes to an activity being worked on. Moreover, he could say the colors and names of items shown to him, and do skip counting between 1 and 50, but he could only read and write his name and surname. However, he had limited skills in understanding and expressing emotions, using appropriate social expressions, and initiating and maintaining communication.

The third participant was 20-year-old Rasim (pseudonymous). As a result of his assessment, Rasim's IQ was determined as 50-55 and he was diagnosed with mild intellectual disability. Rasim had completed primary and secondary school as an inclusive student and was attending a work school while participating in the study. Rasim displayed a performance close to his peers in gross and fine motor skills. He could imitate movements made with items and without items as well as expressions that including two words. Also, he could follow instructions with three or more actions, direct his attention for ten minutes to an activity being worked on, say the colors, shapes, and names of items shown to him, perform simple addition and 
subtraction, and read and write independently. However, he had limited social skills with using appropriate social expressions, asking for help, asking for information, and determining appropriate personal space while communicating. The participants had not had any systematic teaching experience related to an intervention package of computer-presented video modeling and Social Stories.

Peer model. The skills of performing instructions and of initiating and maintaining communication were prerequisites and which peers had these prerequisite skills had been determined by considering the recommendations of their teachers. After the interviews with students and their families, a student whose family had given permission began to participate in the study. The peer model was asked if he wanted to participate in the study, at which point he volunteered to participate in the study. The peer model was a 22-year old male student named Doruk (pseudonymous) who attended the same special education and rehabilitation center as the participants; he had been diagnosed with mild intellectual disability (IQ of 50-69), could repeat instructions composed of three or more words, and had social skills such as initiating and maintaining communication. The participants did not know him. In order to ensure that the peer model exhibited the most correct performance, the peer model was trained for the target skill in sessions once every two days. The following stages were included in the training: (a) explaining the objective of the study and the task of the model, (b) introducing the target skill, (c) being a model in terms of giving the correct response, and (d) role playing and trial. These stages are explained in detail as follows.

(a) Explaining the study's objective and model's task. The following explanation was made to the model. "I want you to teach your friends to say "get better soon." I plan to make a film and get them to watch the film for this purpose. I need your help in this process. I want you to play in this film and be model to them." The questions "Why do we prepare videos?" and "How do you help me?" were asked to the model peer to evaluate whether he understood the study's objective and task. The model peer's correct answers were reinforced verbally (You're great, well done, etc.) while explanations were simply repeated for incorrect answers.

(b) Introducing target skills. At this stage, the researcher explained the target skill verbally as "I expect your friends to say get better soon to someone who is sick."

(c) Being a model in terms of giving the correct response. The researcher was the model for the model peer to show how he needed to behave in the video. For example, the researcher said "Watch me carefully." At that moment someone would come in and cough, sneeze, etc.; when asked how he was, he would reply with "I am very sick." The researcher would then say "Get better soon" while making eye contact with that person. 
(d) Role playing and trial. The researcher and model peer role displayed the behaviors that would be seen in the video. At this stage, the researcher and model peer switched roles. The model peer was asked to exhibit the skills which had been exhibited by the researcher during the previous stage, which gave the model the opportunity to practice the target skills. The role playing continued until the model gave $100 \%$ correct responses for the target skill in three consecutive trials. After each trial, the model's correct responses were reinforced verbally while he was given corrective feedback for incorrect responses. After completing the peer model's training for the video, the video preparation stage began.

Researcher. The researcher, with a doctoral degree in the field of special education, had been working as a psychologist in the participants' educational institution for approximately 10 years. Moreover, the researcher was experienced in providing teaching via video modeling and Social Stories. The researcher had also been conducting studies with the student participants for approximately 5 years.

Observer. Reliability data for the interobserver reliability and procedural reliability data were collected by two independent observers in the study. The observers had twohours training on the target skill and intervention package. In the training, the observers were informed about (a) the purposes of the study, (b) the target skill, (c) the intervention package of computer-presented video modeling and Social Stories, (d) probe sessions, (e) intervention sessions, (f) maintenance sessions, (g) generalization sessions, (h) what constitutes correct and incorrect responses from the participants, and (i) how the researcher is expected to answer participants' correct and incorrect responses.

The people presenting stimuli that elicit the target skill. During the full probe and daily probe sessions, five people from the institution's staff or students who were acquaintances of the participants entered the participants' setting and gave them the opportunity to demonstrate the target skill in order to evaluate their performances. These participants had been informed directly before entering about what they were required to say and how they were required to behave when they went inside. Role playing practices were included in addition to explanations for the institution students. People providing the opportunity to exhibit the target skill were asked to go inside the participants' setting in order to take an item (pencil, eraser, notebook, etc.), then cough or sneeze; when the participants asked them how they were, they were requested to reply "I am sick, very sick."

\section{Settings}

The study was conducted in the individualized education classes of a special education and rehabilitation center in Ankara province. In the study, the stage of getting students to watch the videos as well as the probe and maintenance sessions were conducted 
in individualized education classes where a table and chairs had been placed for the students to sit side-by-side or face-to-face. There was a bean table, cabinet, and two chairs in the individualized education class. Generalization sessions were performed in the waiting room, intervention kitchen, principal's office, and corridors.

\section{Materials}

In order to teach the target skill, a video and a laptop computer for the participants to watch it on were used in the study. A video camera was provided to record all stages of the study. The study began by writing a Social Story for the basis of the video scenario that would be used in teaching the target skill. According to the rules determined by Gray (2000), a Social Story composed of seven descriptive, directive, perspective, and affirmative sentences was written. In order to evaluate the appropriateness of the Social Story, opinions from two experts, one a lecturer in the field of special education and the other with a doctorate in this field, were taken. For this purpose, they were asked to evaluate the story that had been prepared using the Social Story Checklist (Vuran \& Usluer, 2012, p. 177). After the Social Story was finalized, a video describing every sentence in the story was shot. The behavior of the model in the video was noted to be natural; the model's behaviors were neither too fast nor too slow, the voice and speaking of the model and teacher were crystal clear, and the video was direct and of good quality. After the video was shot, the preparation stage began. The video started with the title of the Social Story being read aloud. Each sentence that was read aloud was followed by images describing the sentence, and a video lasting $1 \mathrm{~min} 34 \mathrm{sec}$ was prepared. Expert opinions were received in order to evaluate the appropriateness of the video. It was shown to four experts who were experienced in training with video modeling; they knew about the participants, had attended the trainings given to the observers, and were employed in the center. Two of these four experts were class teachers of students with intellectual disabilities, one of them was a psychologist, and the last was a lecturer in the field of special education. These experts were asked to evaluate the video in terms of the appropriate exhibition of the target skill, the behavior of the model, video streaming, video quality and length, and audibility of the voices. The necessary changes were then made to the video after receiving their opinions and recommendations, and the video was finalized. In this video, while the peer model and researcher are in class, someone knocks on the door and comes in to get something. The person who comes in sneezes or coughs. The researcher asks, "How are you?" The person who has come in says "I am sick, very sick." In response, the peer model makes eye contact with the sick person and says "Get better soon." The sick person smiles and says, "Thank you Doruk. You are so kind." After this, the sick person takes the item and leaves. 


\section{General Procedures}

After preparing the video, a pilot study was first conducted and the experiment process was started. Probe, intervention, maintenance, and generalization sessions were conducted during the general procedures. The intervention occurred through oneon-one training for all sessions. Because the activity itself reinforced all experimental sessions, no reinforcements outside of the sessions were used for correct responses given by the participants. When the participant responded correctly, the approval from the other party was considered as their reinforcement. Incorrect participant responses were ignored in all sessions.

Pilot study. Before the study began, a pilot study was conducted to evaluate the applicability of the intervention package as well as to determine any imperfect or defective aspects so as to improve them. The pilot study was conducted with a 21year old male student with mild intellectual disability. The student had the prerequisite skills for the intervention. At the end of the study, the video and intervention package deemed applicable, and no adaptation was required for the intervention.

Probe sessions. Two different sets of probe data, a full probe set and a daily probe, were collected in the study. The first full probe session was performed in order to collect baseline data while other full probe sessions were performed for all participants just prior to the onset of participant training and immediately after the training criteria had been met. Full probe sessions continued until at least three continuous stable data had been obtained. Daily probe sessions were conducted immediately after training with the intervention package. Daily probe sessions were held until participants exhibited $100 \%$ correct responses for three consecutive sessions, at which point intervention data were collected. The two steps of the probe sessions were (a) giving five opportunities to exhibit the target skill, and (b) recording the responses related to the skill. All probe sessions were designed according to the principles set forth in the baseline phase (Tekin-İftar, 2012b), and arrangements for exhibiting the target behavior were included. Five trials related to the target skill were conducted in every probe session. The institution's staff and one of the students entered the setting where the participant was while coughing or sneezing. After the participant asked how the student was, the student would reply with "I am sick, very sick," giving the participants the opportunity to exhibit the target skill. The people who provided the opportunity for the participant to exhibit the target skill were ensured to behave in the same way in the probe sessions. The probe sessions were conducted in individualized education classes where the participants received their lessons, and after the person said and showed that he was sick to the participant, it was recorded as to whether the participant had made eye contact and said "get better soon" within four seconds. 
Intervention sessions. Probe sessions were carried out immediately before participants were given the opportunity to perform the skill. Seven steps were followed in the intervention sessions: (a) watch the video before entering the setting where the target skill was to be exhibited, (b) watch the video in a designated classroom (in silence and without interruption), (c) provide an attentional cue (such as "I made a very good film for you. Would you like to watch the video with me? If you are ready, I'll start it"), (d) verbally reinforce the participant with attention-directing behavior (when the participant indicates that he is ready verbally or with a gesture, say "You're great!" or "Well done!" etc.), (e) watch the video (start the film with the instructions), (f) verbally reinforce the video-watching behavior of the individual (such as "Well done. You watched our film carefully and quietly. You are super!"), and (g) direct the participant to the setting where the behavior is to be exhibited ("Here we go. Let's go to class.").

After determining the appropriate time and setting for the intervention sessions, each session was initiated by presenting the prepared video to the participants. The watch the video stage was performed as follows. The laptop computer was placed at the eye level of the participant. The researcher gave starting cues to the participant such as "I made a very good film for you. Would you like to watch the film with me? If you are ready, I can start it." When the participant indicated their readiness either verbally or with a gesture, verbal reinforcement was given with expressions such as "You're great," "Well done," and so forth. The video was then played with the instruction of "Watch carefully." In the event the participant was distracted for more than 3 seconds during video playback, attention-grabbing cues were provided and the participants' attention was drawn back to the video. If the participant had appropriately watched the video, he was verbally reinforced afterwards. After watching the video, which lasted approximately 1.5 minutes, intervention sessions were completed by the researcher directing the participant to the setting where the behavior would be exhibited for collecting the daily probe data.

Maintenance. Maintenance data were collected one and four weeks after the last probe session in the study. Maintenance sessions were performed similar to probe sessions. A session comprised of five trials was conducted during the maintenance phase. Training was additionally continued until the target skill was successfully exhibited consecutively at least three times at $100 \%$. This included the use of before-and-after natural behavior stimuli in settings as similar as possible to that of the teaching process, and precautions were taken to ensure that the target skill became permanent.

Generalization. Generalization data were collected by evaluating whether the three participants with intellectual disabilities in emerging adulthood generalized the skill across settings, conditions and people by means of pretest and posttest measurements. Generalization data across settings including the trials were collected 
in different settings of the institution such as the waiting hall, intervention kitchen, principal's office, and corridor. Generalization data across situations were collected by means of the sick people's different expressions such as "My stomach hurts," "I have a headache," or "I caught the flu," as well as different indicators such as blowing their nose or rubbing their stomach. Generalization data across people were collected to include the different people involved in the process. Additionally, the participants were ensured to have met with different people who said and indicated they were sick during the intervention process of the study. Therefore, generalization across people was provided for all participants during the intervention. Generalization pretest sessions had been conducted before the intervention was administered and the posttest sessions were conducted after the intervention sessions had been completed, both as controlled sessions that included five trials per session just like the probe sessions.

\section{Data Collection and Analysis}

Reliability data, effectiveness data, and social validity data were collected in the study. Two types of reliability data, interobserver reliability and procedural reliability, were collected in the study. The formula of [Agreements/(Agreements + Disagreements)] x 100 was used for calculating the interobserver reliability while the formula of [Observed researcher behavior / Planned researcher behavior $\mathrm{x}$ 100] was used for calculating the procedural reliability (Kircaali-İftar \& Tekin, 1997). Interobserver reliability and procedural reliability data were collected by two people who watched the video records; they had been trained as observers and were class teachers of students with intellectual disabilities. Interobserver reliability data were collected from $30 \%$ of all sessions. Procedural reliability data were collected from a third of the probe sessions, half of the maintenance and generalization sessions, and all of the intervention sessions in order to determine the extent to which the intervention package was reliable. Procedural reliability data related to the probe sessions were collected for determining whether the two steps listed under the probe sessions had been conducted, while procedural reliability data related to intervention sessions were collected for determining whether the seven steps listed under the intervention sessions had been conducted. Moreover, data related to the maintenance and generalization phases had been collected as procedural reliability data per the steps which had been recommended for the probe sessions.

Effectiveness of the intervention package data were collected by evaluating the performances of participants with intellectual disabilities in the probe, intervention, maintenance, and generalization sessions. Controlled event recording was used in these sessions. Then graphical analyses were conducted. Moreover, social validity data were collected from participants through semi-structured interviews and from teachers by the Social Validity Questionnaire using the subjective evaluation 
approach in the study. During collection of the social validity data from the teachers, an envelope including an abstract of the study, a written explanation about the intervention package, a CD of the video shot during administration of the intervention package, and a Social Validity Questionnaire were submitted to the teachers. Data collected from the participants with intellectual disabilities and teachers were analyzed descriptively through the subjective evaluation approach.

\section{Findings}

\section{Reliability Findings}

The percentage of interobserver reliability related to the probe, intervention, maintenance, and generalization sessions of each of the three participants was found at $100 \%$ for the target skill. The probe, intervention, maintenance, and generalization sessions were seen to have been performed correctly at $100 \%$ by the researcher.

\section{Effectiveness Findings}

Findings related to the effectiveness of the intervention package were found by analyzing the performances of the participants with intellectual disabilities in the baseline, probe, intervention, maintenance, and generalization sessions. Figure 1 shows the findings from the probe, intervention, and maintenance sessions; Figure 2 shows the findings from the generalization sessions.

Effectiveness findings obtained for Nedim (acquisition, maintenance and generalization). Nedim exhibited the "say 'get better soon"" skill at $0 \%$ accuracy in the baseline; he reached the criteria of $100 \%$ in the third session of the intervention phase. However, the intervention process continued until stable data were obtained. Five intervention-phase sessions in total had been completed by the time Nedim gave $100 \%$ correct responses in three consecutive sessions. Moreover, Nedim was noted to have given $100 \%$ correct responses in the entire first, second, and third full probe sessions and maintenance sessions. When analyzing the generalization data, Nedim was seen to correctly exhibit the target skill at $0 \%$ in the pretest session and at $100 \%$ in the posttest session.

Effectiveness findings obtained for İsmail (acquisition, maintenance and generalization). İsmail exhibited the "say "get better soon" skill at $0 \%$ accuracy in the baseline, while he reached the criteria of $100 \%$ in the fourth session of the intervention phase; intervention sessions were ended when İsmail gave $100 \%$ correct responses in three consecutive sessions. Moreover, it was noted that İsmail gave $0 \%$ correct responses in the first full probe session, 100\% correct responses in the second and third full probe sessions as well as the first maintenance session, and $80 \%$ correct 
responses in the second maintenance session. In analyzing the generalization data, İsmail was seen to exhibit the target skill at $0 \%$ in the pretest session while reaching $100 \%$ correct responses in the posttest session.

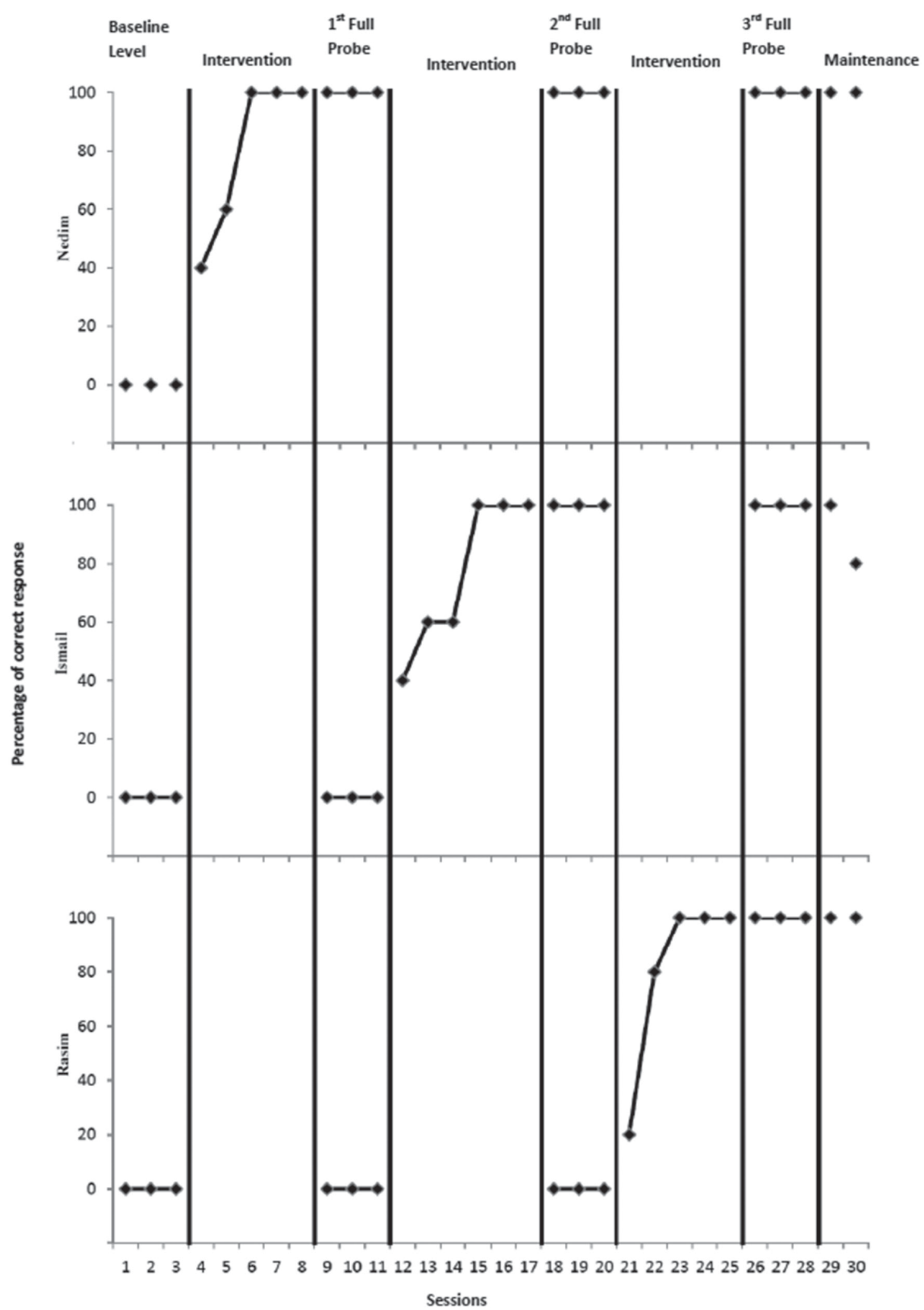

Figure 1: Participants' target social-skill learning levels (Daily probe session data were used to meet the criteria in the training sessions). 
Effectiveness findings obtained for Rasim (acquisition, maintenance and generalization). While Rasim had exhibited the "say 'get better soon"” skill at $0 \%$ accuracy in the baseline, he reached the criteria of $100 \%$ by the third session and gave $100 \%$ correct responses in three consecutive sessions, which ended the intervention. A total of five intervention sessions were performed for Rasim. Moreover, Rasim was noted to have given $0 \%$ correct responses in the first two full probe sessions, and $100 \%$ correct responses in the last probe session and the maintenance sessions. In analyzing the generalization data, Rasim was seen to have exhibited the target skill at $0 \%$ in the pretest session; he achieved $100 \%$ correct responses in the posttest session.

\section{Social Validity Findings}

In the study using the subjective evaluation approach, social validity data were collected from the participants with intellectual disabilities through semi-structured interviews and from the participants' teachers through the Social Validity Questionnaire which was then analyzed.

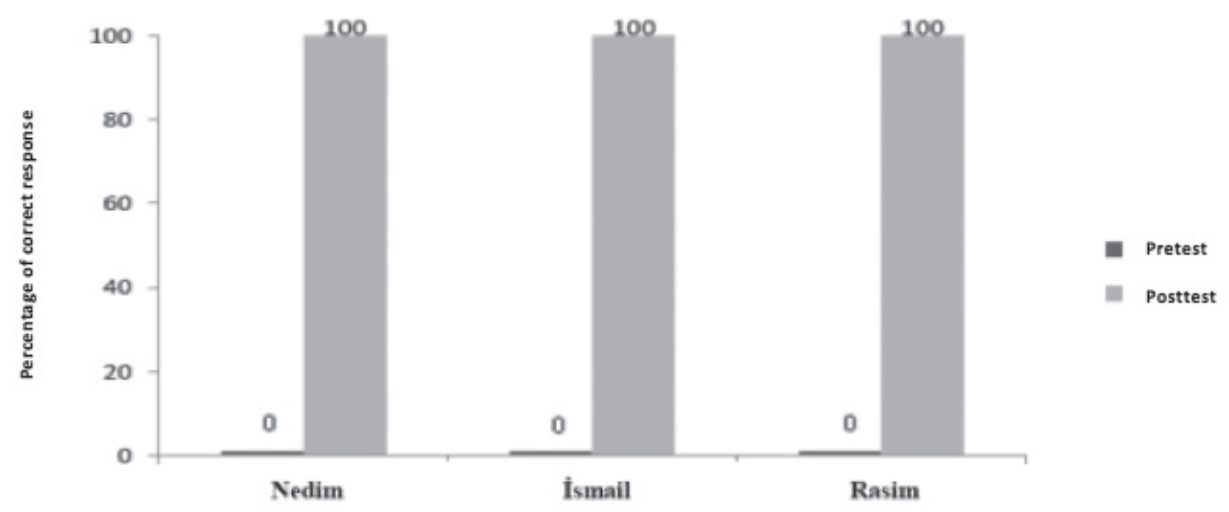

Figure 2: Pretest-posttest generalization data of participants.

Social validity findings obtained from participants with intellectual disabilities. Social validity data were collected from the participants with intellectual disabilities using semi-structured interviews. The participants were asked a total of eight questions, two open-ended questions and 6 closed-ended questions about the skill being taught and intervention package used in the study. Collected data were analyzed descriptively. Participants expressed in their answers about skills being taught that they had liked learning a new skill and had exhibited the skill in their daily life, and this situation made the individuals around them very happy. Moreover, the participants stated in their answers about the intervention package that they had liked the computer-presented teaching package, that they could communicate with the researcher easily, and that they wanted to learn new skills with this intervention 
package. Participants listed what they liked most in the study as learning a new thing and watching the video. Additionally, the participants mentioned that they hadn't disliked anything about the study.

Social validity findings obtained from the participants' teachers. Social validity data were collected from the teachers of participants via the subjective evaluation approach. The Social Validity Questionnaire was comprised of 11 questions, 2 open-ended and 9 closedended questions. The social validity data were analyzed descriptively after being collected. Teachers expressed that the skill being taught had been useful for the students, that the students could use these skills in different settings, and that the students were reinforced in natural settings when they exhibited these skills. Considering the teachers' opinions about the intervention package, video preparation was not stated as a financial burden for them; two of teachers stated that video preparation was a burden in terms of time and one stated they had little opinion on this issue. Additionally, all teachers indicated that the intervention package was easy to implement and did not limit the behaviors of the students, that positive changes in the lives of students had occurred as a result of the intervention, and that this change had occurred in the presence of different settings and people. Also, some responses to the question of which parts of the intervention package was liked most as answered by the teachers were as follows: the intervention package ensured that students learned the skill without the need of warning students constantly; it directed students to think and reconsider, and the intervention package was seen to be entertaining to the students. The teachers stated that no situation related to the intervention package had been disliked. Consequently, the social validity findings that were collected from teachers via the subjective evaluation approach revealed that teachers had positive opinions about the target skill, the intervention of computer-presented video modeling and Social Stories, and the results of the study.

\section{Discussion}

The purpose of this study was to investigate the effectiveness of computer-presented video modeling and Social Stories as an intervention package for teaching social skills to individuals with intellectual disabilities in emerging adulthood. Moreover, using a subjective evaluation approach, social validity data for the study were collected from the participants with intellectual disabilities through semi-structured interviews and from the teachers of the participants using a Social Validity Questionnaire. According to the study findings, individuals with intellectual disabilities in emerging adulthood had acquired the target social skill as a consequence of this intervention package; they were able to maintain the acquired social skill one and four weeks after the study had been completed, and they generalized this skill across settings, conditions, and people. The social validity findings collected via the subjective evaluation approach revealed that participants and teachers of the participants had positive opinions about the target skill, intervention package, and study results. 
Data were assessed in the study in two forms: empirical criteria and clinical criteria. The effectiveness of the intervention was assessed using graphical analysis in the empirical criteria assessment. According to the findings of the assessment, the intervention package was effective in teaching target social skills to the participants. This finding complies with the findings in the study that had investigated the effectiveness of video modeling, Social Stories, and combined interventions presenting video modeling and Social Stories together on social skills (Cigrand, 2011; Kagohara et al., 2013; Olçay-Gül \& Tekin-İftar, 2012; Olçay-Gül \& Vuran, 2010; Sansosti \& Powell-Smith, 2008; Scattone, 2008). However, this study differed from the aforementioned studies in terms of participant characteristics (participant's ages ranged between 20 and 25 and they had intellectual disabilities), intervention features (computer-presented video modeling and Social Stories), and peer model characteristics (the peer model also had intellectual disability). Therefore, the study is considered to contribute to the literature thanks to these features. Additionally, the study is thought to be able to lead families, teachers, and experts in terms of showing that students in emerging adulthood cannot benefit from the natural learning opportunities of social expressions which they mostly hear in daily life; these students require systematic instruction in social skills. Using peers with intellectual disabilities as models is also believed to be able to both contribute to the literature and shed light on teachers and experts in terms of showing that an individual can learn appropriate behaviors and skills not only from peers with typical development but also from peers with intellectual disabilities.

Maintenance data were collected one and four weeks after the study had been completed. Maintenance data revealed that the target social skills acquired by the participants had been maintained after completion of the intervention. Maintenance data collected from many studies that examined the effectiveness of interventions using video modeling, Social Stories, or the combination of the two showed that participants had maintained the acquired skills after the intervention terminated (Akmanoğlu \& Tekin-İftar 2011; Bidwell \& Rehfeldt, 2004; Croizer \& Tincani, 2006; Delano, 2003; Delano \& Snell, 2006; Gena et al., 2005; Graetz, 2003; Keyworth, 2004; Kuoch \& Mirenda, 2003; Nikopoulos \& Keenan, 2003; Özdemir, 2008; Quilty, 2007; Reichow \& Sabornie, 2009; Sansosti \& Powell-Smith, 2008; Schenider \& Goldstein, 2010; Swaine, 2004; Washburn, 2006; Wert \& Neisworth, 2003; Xin \& Sutman, 2011). The maintenance findings of this study were similar to findings from other research; this supports the findings in the literature. The intervention did not finish after achieving the first criterion but continued until the behavior was seen to be maintained. This situation is considered effective in ensuring maintenance. Moreover, performing the intervention in natural settings and using natural antecedent and consequence can contribute to maintaining acquired skills.

Generalization data had also been collected from the participants during the study. In the generalization sessions conducted with the participants, pretest and posttest data 
were collected in relation to whether the participants had generalized their acquired skill across settings, conditions, and people. According to the study findings, participants had generalized their acquired skills at $100 \%$ accuracy. This finding complies with the generalization findings obtained from study in which a video modeling, Social Story or combined video modeling and Social Story had been used (Akmanoğlu \& Tekin-İftar 2011; Bernad-Ripoll, 2007; Delano, 2003; Delano \& Snell, 2006; Gena et al., 2005; Graetz, 2003; Hagiwara \& Myles, 1999; Keyworth, 2004; Nikopoulos \& Keenan, 2007; Olçay-Gül, 2012; Olçay-Gül \& Vuran, 2010; Reichow \& Sabornie, 2009; Sansosti \& Powell-Smith, 2008; Scattone, 2008; Smith, 2001). Another point related to the obtained generalization data were the use of natural iterations in the study (Tekin-İftar, 2012c). The study was conducted with natural iterations, and its effect was measured on individual participants and across all participants. Additionally, the study's interventions were carried out in front of different people. This situation is also considered effective in generalizing the acquired skill across different people. Because of all of these, the generalization features and findings of the study can be considered as strengths of the study, and these findings support the related literature.

As previously mentioned, the study data had also been evaluated in terms of clinical criteria. In the clinical criteria measurements, the importance of the effect obtained by the intervention in terms of both the participants and the people around them was assessed by collecting social validity data. The social validity findings collected from the teachers and participants also revealed that participants and teachers had considered the skill taught in the study to be significant and useful. According to the social validity data collected from participants related to the intervention package of the study, the participants stated that they had found the intervention package employed during training entertaining; they liked the intervention package very much and wanted to learn different skills using the same strategy. The social validity data collected from teachers revealed that the teachers considered the intervention package easy to use, cost effective, and entertaining for students. Consequently, the opinions of both participants and teachers related to the study results were seen to be positive. This finding complies with the social validity findings obtained from other research conducted that had used the subjective evaluation approach on this subject (Akmanoğlu \& Tekin-İftar, 2011; Croizer \& Tincani, 2006; Delano, 2003; Dodd at al., 2008; Emecen, 2008; Graetz, 2003; Nikopoulos \& Keenan, 2003; Sansosti \& Powell-Smith, 2008; Scattone, 2008). However, data had only been collected from the teachers and families of participants in these studies using the subjective evaluation approach. Therefore, collecting social validity data from the participants themselves can be said to contribute to the literature, and the social validity findings of this study can be said to strengthen the relative literature.

Considering both the current and previous study, the following results can be discerned. Intervention packages of computer-presented video modeling and Social 
Stories can be used effectively to teach social skills to individuals with intellectual disabilities. One could say that this intervention package was an entertaining, timeeffective strategy when considering the following characteristics: (a) the interventions lasted for approximately 5 minutes. Thus, they were very effective in terms of time, considering that individuals with developmental disability get individualized training two hours every week in special education and rehabilitation centers and that each session lasts 50 minutes on average. Since they are educated in different developmental fields and skills within this time period, training that can be provided in a 5 minute window is important in terms of ensuring the use of the education hour effectively. (b) Both participants and teachers expressed that the intervention package had been found entertaining by the students. Therefore, intervention package can be enjoyed by individuals with disabilities. (c) Once a video is prepared, it can be used over and over again, as well as with other individuals with disabilities.

In addition to this, some limitations were encountered while conducting the study. The most significant limitation was that preparation was required before the training. The video preparation process was time-consuming and required know-how. Writing the Social Story took 5 minutes, training the model took 90 minutes, shooting the video took 30 minutes (while working with a peer with intellectual disability), and preparation of the video took 20 minutes. In other words, 2.5 hours was required to make the video ready for teaching. However, this limitation can be considered minimal and the effectiveness of the strategy greater thanks to the repeatability of the prepared videos for different individuals.

Consequently, recommendations about the intervention and further research can be given as a result of the findings and observations obtained during the study. As for the intervention, the inclusion of computer-presented video modeling and Social Stories for teaching skills in different developmental fields as well as the use of peers with disabilities as models can be recommended to family members, experts in the field, and teachers. As for future research, the effectiveness of interventions of computerpresented video modeling and Social Stories in teaching different socials skills (self-care, daily life, independent life skills) can be recommended for investigation with different people (e.g. teacher, peer) and in different settings (e.g. home); these interventions should be included in studies on effectiveness in teaching social skills using a small group teaching arrangement, and the effectiveness of interventions in which videos are presented using technological tools such as an iPad or tablet as opposed to a computer should be examined. Additionally, research can be planned in which social validity data are collected by using the social comparison approach along with the subjective evaluation approach. 


\section{References}

Akmanoğlu, N., \& Tekin-İftar, E. (2011).Teaching children with autism how to respond to the lures of strangers. Autism: The International Journal of Research and Practice, 15, 1-8.

American Psychiatric Association (2013). Intellectual disability. Retrieved from www.dsm5.org/ Documents/Intellectual Disability Fact Sheet.pdf

Andrews, S. (2004). Using Social Stories to increase reciprocal social interactions and social comprehension in school-aged children diagnosed with autism (Doctoral dissertation). California School of Professional Psychology, San Diego.

Avcıŏlu, H. (2013). Zihinsel yetersizliği olan öğrencilere selam verme becerisinin öğretiminde videoyla model olmanın etkililiği [The effectiveness of video modeling on students with intellectual disabilities on teaching the skill of how to say hello]. Kuram ve Uygulamada Eğitim Bilimleri Dergisi, 13, 455-477.

Baker, J. E. (2004). Social skills training for children and adolescents with Asperger Syndrome and social-communication problems. Kansas: Autism Asperger Publishing.

Barry, L., \& Burlew, S. (2004). Using Social Stories to teach choice and play-skills to children with autism. Focus on Autism and Other Developmental Disabilities, 19, 45-51.

Begun, W. R. (Ed.). (1996). Social skills lessons and activities for grades 7-12. San Francisco: Jossey-Bass.

Bellini, S., Akullian, J., \& Hopf, A. (2007). Increasing social engagement in young children with autism spectrum disorders using self-modeling. School Psychology, 36, 80-90.

Bernad-Ripoll, S. (2007). Using a self-as-model video combined with Social Stories to help a child with Asperger Syndrome understand emotions. Focus on Autism and Other Developmental Disabilities, 22, 100-106.

Bidwell, M. A., \& Rehfeldt, R. A. (2004). Using video modeling to teach a domestic skill with an embedded social skill to adults with severe mental retardation. Behavioral Intervention, 19, $263-274$.

Buggey, T. (2005). Video self-modeling applications with students with autism spectrum disorder in a small private school setting. Focus on Autism and Other Developmental Disabilities, 20, $52-73$.

Charlop-Christy, M. H., \& Daneshvar, S. (2003). Using video modeling to teach perspective taking to children with autism. Journal of Positive Behavior Interventions, 5, 12-22.

Charlop-Christy, M. H., Le, L., \& Freeman, K. A. (2000). A comparison of video modeling with in vivo modeling for teaching children with autism. Journal of Autism and Developmental Disorders, 30, 537-552.

Cigrand, D. L. (2011). School counselors' use of the combination Social Stories ${ }^{T M}$ and video modeling intervention for social skills development of students diagnosed with autism spectrum disorders: A qualitative criticism of the perceptions of multidisciplinary team members (Doctoral dissertation, The University of Iowa). Retrieved from http://ir.uiowa.edu/etd/2842

Croizer, S., \& Tincani, M. (2006). Effects of Social Stories on prosocial behavior of preschool children with autism. Journal of Autism \& Developmental Disorders, 37, 1803-1814.

Çiftçi, İ., \& Sucuoğlu, B. (2004). Bilişsel süreç yaklaşımıyla sosyal beceri öğretimi [Teaching social skills through the cognitive process approach]. Ankara, Turkey: KökYayıncılık.

D'Ateno, P., Mangiapanello, K., \& Taylor, A. B. (2003).Using video modeling to teach complex play sequences to a preschooler with autism. Journal of Positive Behavior Intervention, 5, 5-11.

Delano, M. E. (2003). The effects of Social Stories on the social engagement of children with autism (Doctoral dissertation). University of Virginia, Virginia.

Delano, M. E., \& Snell, M. E. (2006). The effects of Social Stories on the social engagement of children with autism. Journal of Positive Behavior Interventions, 8, 29-42. 
Dodd, S., Hupp, S. D. A., Jewell, D. J., \& Krahn, E. (2008). Using parents and sibling during a Social Story intervention for two children diagnosed with PDD-NOS. Journal of Developmental and Physical Disabilities, 20, 217-229.

Emecen, D. D. (2008). Zihinsel yetersizlikten etkilenmiş öğrencilere sosyal becerilerin kazandırılmasında doğrudan öğretim ve bilişsel süreç yaklaşımları ile yapılan öğretimin etkililiklerinin ve verimliliklerinin karşılaştırılması [The effectiveness and efficiency of teaching students with mental disabilities in gaining social skills: A comparison of the direct instruction and cognitive approaches]. (Doctoral dissertation, Gazi Üniversitesi, Eğitim Bilimleri Enstitüsü, Ankara, Turkey). Retrieved from https://tez.yok.gov.tr/UlusalTezMerkezi/

Eripek, S. (2009). Zihinsel yetersizliği olan çocuklar [Children with intellectual disabilities]. Ankara, Turkey: Maya Akademi.

Gena, A., Couloura, S., \& Kymissis, E. (2005). Modifying the affective behavior of preschoolers with autism using invivo or video modeling and reinforcement contingencies. Journal of Autism and Developmental Disorders, 35, 545-556.

Graetz, J. E. (2003). Promoting social behaviors for adolecents with autism using Social Stories (Doctoral dissertation). George Mason University, Fairfax VA.

Graetz, J. E., Mastropieri, M. A., \& Scruggs, T. E. (2006). Show time: Using video self-modeling to decrease inappropriate behavior. Teaching Exceptional Children, 38, 43-48.

Gray, C. A. (1998). Social Stories and comic strip conversations with students with Asperger Syndrome and high functioning autism. In E. Schopler, G. B. Mesibov, \& L. J. Kunce (Eds.), Asperger Syndrome or high functioning autism? (pp. 167-198). New York, NY: Plenum Press.

Gray, C. A. (2000). Writing social stories with Carol Gray: Accompanying workbook to DVD. Arlington, TX: Future Horizons.

Gray, C. A., \& Garand, J. D. (1993). Social Stories: Improving responses of students with autism with accurate social information. Focus on Autistic Behavior, 8, 1-10.

Hagiwara, T., \& Myles, B. (1999). A multimedia Social Story intervention: Teaching skills to children with autism. Focus on Autism and Other Developmental Disabilities, 14, 82-95.

Heward, W. L. (2003). Exceptional children: An introduction to special education (7th ed.). New York, NY: Prentice-Hall.

Hourcade, J. (2002). Mental retardation. Retrieved from http://clsf.info/Articles/mental retardation definition.htm

Huang, W., \& Cuvo, A. J. (1997). Social skills training for adults with mental retardation in jobrelated settings. Behavior Modification, 21, 3-44.

Kagohara, D. M., Achmadi, D., Van der Meer, L., Lancioni, G. E., O’Reilly, M. F., Lang, R., ... Sigafoos, J. (2013). Teaching two students with Asperger Syndrome to greet adults using Social Stories and video modeling. Journal of Developmental and Physical Disabilities, 25, 241-251.

Kalyva, E., \& Agaliotis, I. (2009). Can Social Stories enhance the interpersonal conflict resolution skills with LD? Research in Developmental Disabilities, 30, 192-202.

Kennedy, C. H. (2005). Single-case designs for educational research. Boston, MA: Pearson Merrill Prentice Hall.

Keyworth, P. L. W. (2004). The effects of Social Stories on the social interactions of students with autism (Unpublished doctoral dissertation).The University of Iowa, Iowa City, IA.

Kırcaali-İftar, G., \& Tekin, E. (1997).Tek-denekli araştırma yöntemleri [Single-subject research methods]. Ankara, Turkey: Türk Psikologlar Derneği Yayınları.

Kroeger, K. A., Schultz, R. J., \& Newsom, C. (2007). A comparison of two group-delivered social skills programs for young children with autism. Journal of Autism Developmental Disorder, 37, 808-817. 
Kuoch, H., \& Mirenda, P. (2003). Social Story intervention for young children with autism spectrum disorders. Focus on Autism and Other Developmental Disabilities, 18, 219-227.

Lorimer, P. A., Simpson, R. L., Myles, B. S., \& Ganz, J. B. (2002). The use of Social Stories as a preventative behavioral intervention in a home setting with a child with autism. Journal of Positive Behavior Interventions, 4, 53-60.

McCoy, K., \& Hermansen, E. (2007). Video modeling for individuals with autism: A review of model types and effects. Education and Treatment of Children, 30, 183-213.

Nikopoulos, C., \& Keenan, M. (2003). Promoting social initiation in children with autism using video modeling. Behavioral Interventions, 18, 87-108.

Nikopoulos, C., \& Keenan, M. (2006). Video modeling and behavior analysis: A guide for teaching social skills to children with autism. London, UK: Jessica Kingsley Publishers.

Nikopoulos, C., \& Keenan, M. (2007). Using video modeling to teach complex social sequences to children with autism. Journal Autism Developmental Disorder, 37, 678-693.

Norris, C., \& Datillo, J. (1999). Evaluating effects of a Social Story intervention on a young girl with autism. Focus on Autism and Other Developmental Disabilities, 14, 180-186.

Olçay-Gül,S. (2012). Ailelerce sunulan sosyal öykülerin otizm spektrum bozukluğu olan ergenlerin sosyal becerilerine etkileri [The effect of Social Stories offered by the family on the social skills of adolescents with autism spectrum disorder]. Ankara, Turkey: Eğitenkitap.

Olçay-Gül, S., \& Tekin-İftar, E. (2012). Otizm spektrum bozukluğu tanısı olan bireyler için sosyal öykülerin kullanımı [The use of Social Stories for individuals with autism spectrum disorders]. Ankara Üniversitesi Eğitim Bilimleri Fakültesi Özel Ĕgitim Dergisi, 13, 1-20.

Olçay-Gül, S., \& Vuran, S. (2010). Sosyal becerilerin öğretiminde video model yöntemiyle yürütülen araștırmaların analizi [Analysis of the research conducted with the video model method in teaching social skills]. Kuram ve Uygulamada Ĕgitim Bilimleri, 10, 249-274.

Özdemir, S. (2008). The effectiveness of Social Stories on decreasing disruptive behaviors of children with autism: Three case studies. Journal of Autism and Developmental Disorders, 38, $1689-1696$.

Quilty, K. M. (2007). Teaching paraprofessionals how to write and implement Social Stories for students with autism spectrum disorders. Remedial and Special Education, 28, 182-189.

Reichow, B., \& Sabornie E. J. (2009). Brief report: Increasing verbal greeting initiations for a student with autism via a Social Story intervention. Journal of Autism and Developmental Disorders, 39, 1740-1743.

Reichow, B., Volkmar, F. R., \& Cicchetti, D. V. (2008). Development of the evaluative method for evaluating and determining evidence-based practices in autism. Journal of Autism and Developmental Disorders, 38, 1311-1319.

Sansosti, F. J., \& Powell-Smith, A. K. (2008). Using computer presented Social Stories and video models to increase the social communication skills of children with high functioning autism spectrum disorders. Journal of Positive Behavior Interventions, 10, 162-178.

Sargent, L. R. (1991). Social skills for school and community: Systematic instruction for children and youth with cognitive delay. Washington, D. C: The Division on Mental Retardation of the Council for Exceptional Children.

Sazak, E. (2003). Zihinsel engelli birey için hazırlanan akran aracılı sosyal beceri öğretim programının etkililiğinin incelenmesi [Examintation of the effectiveness of peer-mediated social skills curriculum prepared for people with intellectual disabilities]. (Master's thesis). Retrieved from https://tez.yok.gov.tr/UlusalTezMerkezi/

Scattone, D. (2002). Increasing appropriate social interactions of children with autistic spectrum disorders using Social Stories (Doctoral dissertation). University of Southern Mississippi, Mississippi.

Scattone, D. (2008). Enhancing the conversation skills of a boy with Asperger's Disorder through social stories and video modeling. Journal of Autism and Developmental Disorders, 38, 395-400. 
Schneider, N., \& Goldstein, H. (2010). Using Social Stories and visual schedules to improve socially appropriate behaviors in children with autism. Journal of Positive Behavior Interventions, 12, 149-160.

Smith, C. (2001). Using Social Stories to enhance behavior in children with autistic spectrum difficulties. Educational Psychology in Practice, 17, 337-345.

Sugai, G., \& Lewis, T. J. (1996). Preferred and promising practices for social skills instruction. Focus on Exceptional Children, 29, 1-23.

Swaine, J. M. (2004). Teaching language skills to children with autism through the use of Social Stories (Doctoral dissertation). Dalhousie University, Halifax NS.

Sucuoğlu, B. (2010). Zihin engeli tanımları: Sınıflandırma ve yaygınlık [Definitions of mental disability: Classification and prevalence]. In B. Sucuoğlu (Ed.), Zihin engelliler ve eğitimleri (3rd. ed., pp. 49-86). Ankara, Turkey: Kök Yayıncılık.

Tekin-İftar, E. (2012a). Çoklu yoklama modelleri [Multiple probe designs]. In E.Tekin-İftar (Ed.), Eğitim ve davranış bilimlerinde tek denekli araştırmalar (pp. 217-254). Ankara, Turkey: Türk Psikologlar Derneği Yayınları.

Tekin-İftar, E. (2012b). Tek-denekli araştırmalar ve temel kavramlar [Single-subject research and basic concepts]. In E. Tekin-İftar (Ed.), Ĕgitim ve davranış bilimlerinde tek-denekli araştırmalar (pp. 15-41). Ankara, Turkey: Türk Psikologlar Derneği Yayınları.

Tekin-İftar, E. (2012c). Grafik ve görsel analiz [Graphic and visual analysis]. In E. Tekin-İftar(Ed.), Eğitim ve davranış bilimlerinde tek-denekli araştırmalar (pp. 133-155). Ankara, Turkey: Türk Psikologlar Derneği Yayınları.

Toplis, R., \& Hadwin, A. J. (2006). Using Social Stories to change problematic lunchtime behavior in school. Educational Psychology in Practice, 22, 53-67.

Vuran, S. (2012). Sosyal yeterlikle ilişkili kavramlar ve sosyal yeterliğin bileşenleri [Concepts and components of social competence]. In S. Vuran (Ed.), Sosyal yeterliğin geliştirilmesi: Sosyal beceri yetersizliği gösteren çocuklar için (pp. 15-42). Ankara, Turkey: VizeYayıncılık.

Vuran, S., \& Usluer, C. (2012). Sosyal Öyküler [Social Stories]. In S. Vuran (Ed.), Sosyal yeterliğin geliştirilmesi: Sosyal beceri yetersizliği gösteren çocuklar için (pp. 163-181). Ankara, Turkey: Vize Yayıncilık.

Washburn, P. K. (2006). The effects of a Social Story intervention on social skills acquisition in adolescents with Asperger's Syndrome (Doctoral dissertation). University of Florida, Florida.

Wert, B. Y., \& Neisworth, J. T. (2003). Effects of video self-modeling on spontaneous requesting in children with autism. Journal of Positive Behavior Interventions, 5, 30-34.

Wheeler, K. L. (2005). The power of Social Stories: A strategy for students with autism spectrum disorder (Master's thesis). California State University, California.

Wilkinson, L. (2010). The effect of Social Stories and peer video modeling to increase social pragmatics in children with autism (Master's thesis). Northeastern University, Boston.

Xin, J. F., \& Sutman, F. X. (2011). Smart board in teaching Social Stories to students with autism. Teaching Exceptional Children, 43, 18-24. 